\title{
The social meaning of money in social interaction of boarding students
}

\author{
Romi Mesra1, Erianjoni ${ }^{2}$, Fitri Eriyanti ${ }^{3}$ \\ ${ }^{123}$ Universitas Negeri Padang, Padang - Indonesia, (romimesra16@gmail.com )
}

\begin{abstract}
The purpose of this research are to reveal social symbols of money, identify the symbolic meaning of money, and explain the social impact of money among boarding students, as well as disclosed by Weber (1978) seeing money is the most perfect means for economic and social transactions. Various studies relating to the meaning of money that has been done previously did not elaborate in depth about it. This researh used mixed method by using interview technique conducted with 79 college boarding house student, boarding owner, societies, local official goverment as informants of this study, the quetionaries shared for 69 of college boarding students and observation. The result of this research: social symbol of money are life style, clothes, community, boarding house, university, hangout, vehicle, food, and crisis month. The symbolic meaning of money are there is money there is friend, there are no problem cannot be solved by money, money is instrument; (money is an instrument to join a community, to have fun, and to doing mobility), money is god, money is a goal, money is life. Positive impact of money are to make easy to do mobility and to fullfil life necessaries. Negatif impacts of money are having fake friend, causing debt, and conflict. Financial management are saving money on ATM, avoiding buyin un-necessary things, deposite to the owner of boarding house, and scheduling remittances.
\end{abstract}

Keywords: social meaning, money, social interaction, boarding students

\section{Introduction}

The purpose of this research are to reveal social symbols of money, identify the symbolic meaning of money, and explain the social impact of money among boarding students, as well as disclosed by Weber (1978) seeing money is the most perfect means for economic and social transactions. Various studies relating to the meaning of money that has been done previously did not elaborate in depth about it.

The use of money sweeps our daily lives by calculating and weighing, with determinations of decisions based on numbers and by continuously emphasizing quantitative units beyond their qualitative values. (Duncan, 1997: 21). For Simmel (1978) and Weber (1978), money not only has the ability to abstractly calculate an object but also an impersonal instrument (Damsar, 2006: 27). 
The reality of boarding students who living in Gunung Pangilun Village, Padang city, in the background of customs and traditions full of diversity because in general they come from different regions and also different university. This diversity also encourages researchers to choose boarding students as the object of research althought there many criteria available in the community.

Research related to the social meaning of money has often been done by previous researchers, as well as Diana (2011) in his research "the social meaning of money for poor households, case study: poor households in Kuranji Village, Kuranji Subdistrict, Padang City concluded that the social meaning of money for poor households include: money of something important and valuable, no people money so stress, money to facilitate social activities, money symbol status picture, money used for workship.

Wati (2014) in his research "The Meaning of Borrowed Money (Phenomenological Study of the Meaning of Borrowing Debtor BPR Delta Malang in the City of Sisir Batu" concludes that in the use of borrowed money not always for business capital but also for consumption with the assumption to improve they social status. The relevant study close to this research is Diana (2011) but the findings are still superficial, and can still be developed.

Various studies relating to the meaning of money that has been done previously did not elaborate in depth about the symbol of money, the symbolic meaning of money, the social impact of money on boarding students and money management strategies by boarding students.

Also, as Duncan puts it in his book "the sociology of money": It is strange how little sociology and anthropology talk about the money that plays a role in human relationships (Duncan 1997: 3). Based on this background, this study aims to answer the following questions: 1) What is the social symbol of money among boarding students?; 2) What is the symbolic meaning of money among boarding students?; 3) What is the social impact of money among boarding students?

\section{Method}

The method used in this research is mixed methods. According to Creswell (2010: 5), mixed research is a research approach that combines qualitative and quantitative research. Another definition of mixed methods is the practice of using different types or styles, different methods of data collection in a study or program in the same study, eg measuring variables with surveys as well as archival data, testing hypotheses with both experimental and non experimental methods, or using qualitative fieldwork for developed a theoretical interpretation of the findings of a quantitative survey (Tashakkori and Teddli, 2010: 517).

In this study researchers used quantitative data such as questionnaires as a means of collecting data to supplement qualitative data interviews and observations. Researchers use a questionnaire to accommodate the number of boarding students are quite a lot so it is more helpful to get the necessary data.

This research is generally conducted in the community environment of Gunung Pangilun Village, Padang City, especially in the boarding house in Gunung Pangilun Village, Padang City. The location of these select researchers is related to the diverse backgrounds of boarding students and because this boarding houses close to several campuses around the local community.

Informants in this study were taken using Purposive Sampling technique where the researchers determine certain criteria that must be met by people who will be the source of information. These criteria must ensure the validity of the data collected (Afrizal, 2008: 101). Informants in this study were 79 people consisting of students who have minimal boarding more than 1 month live in the community, local government, boarding house owners, parents or guardian boarding students, and communities in the Gunung Pangilun Village, Padang city. 
Techniques and data collection tools used in this research are (a). In-depth interviews, according to Taylor, in-depth interviews are an unstructured interview, conducted repeatedly between the interviewer and the informant (Afrizal, 2008: 97-98). (b). Observation, observation activities conducted in the form of half-involved observation or the researcher only acts as an observer in which the researcher is not fully involved in the life of the community, the researchers determine their own effective time in relation to the community to make observations and identify the phenomena that occur (Jauhari , 2010: 135). (c) Questionnaire, the questionnaire method is a series or list of questions organized systematically, then sent to be filled by the respondent. Once completed, the questionnaire is sent back or returned to the officer or researcher. (Bungin, Burhan, 2005: 133).

The technique of examining the validity of the data used in this research, Lincoln and Guba (Moleong, 2013: 326) explains that in strengthening the validity of the research findings data can use the standard data validity consisting of credibility,transferability,defendabilit, and confirmability. Data analysis technique used in this research is qualitative data analysis technique of Miles and Hubermen model which there are 3 (three) stages, they are: data analysis phase, data presentation stage, and conclusion drawing stage.

\section{Results and Discussion}

Table 1. Social Symbols of Money

\begin{tabular}{lll}
\hline NO & & \multicolumn{1}{c}{ SOCIAL SYMBOLS OF MONEY } \\
\cline { 2 - 3 } $\mathbf{1}$ & Life style & \\
$\mathbf{2}$ & Clothes & \\
$\mathbf{3}$ & Community & \\
$\mathbf{4}$ & Boarding House & \\
$\mathbf{5}$ & University \\
$\mathbf{6}$ & Hangout \\
$\mathbf{7}$ & Vehicle & \\
$\mathbf{8}$ & Food & \\
$\mathbf{9}$ & crisis month \\
\hline
\end{tabular}

Table 2. The Symbolic Meaning of Money Among Boarding Students

\begin{tabular}{ll}
\hline NO & \multicolumn{1}{c}{ The Symbolic Meaning Of Money } \\
\cline { 2 - 3 } $\mathbf{1}$ & There is money there is friend \\
$\mathbf{3}$ & There are no problem cannot be solved by money \\
& Money is instrument: \\
& Money is instrument to join a community \\
& Money is an instrument to have fun \\
$\mathbf{5}$ & Money is an instrument to doing mobility \\
$\mathbf{6}$ & Money is god \\
\hline
\end{tabular}


Tabel 3. The Social Impact of Money Among Boarding Students

\begin{tabular}{cl}
\hline NO & \multicolumn{1}{c}{ The Social Impact of Money } \\
\cline { 2 - 3 } $\mathbf{1}$ & Positive Impact: \\
& Easy to doing mobility \\
$\mathbf{2}$ & To fullfill life necessaries \\
$\mathbf{3}$ & Negative Impact: \\
& Fake Friends \\
$\mathbf{4}$ & Causing debt \\
$\mathbf{5}$ & Conflict \\
\hline
\end{tabular}

Tabel 4. The management strategy of Money of Boarding Students

\begin{tabular}{ll}
\hline NO & \multicolumn{1}{c}{ The Management Strategy of Money } \\
\cline { 2 - 3 } $\mathbf{1}$ & Savindings \\
$\mathbf{2}$ & Avoiding buyin un-necessary things \\
$\mathbf{3}$ & Deposite to the owner of boarding house \\
$\mathbf{4}$ & Scheduling remittances \\
\hline
\end{tabular}

\section{Social Symbol of Money Among Boarding Students}

Life Style, in the theory of symbolic interactionism it is explained that man acts on something based on the meanings that exist on that thing for them. Likewise this lifestyle is the result of meaningful material or money for boarding students who have it so it will be tangible on the lifestyle.

Clothes, when there are rich people who wear good clothes and expensive maybe we will get used to because that's how the mainstream dress style of the rich and everyone will react in accordance with the results of the interpretation process is then a stimulus and the way people respond to the actions of people other.

Community, this is an explanation of the theory of symbolic interactionism that in reality it can be seen that a community is synonymous with symbols, such as a gym community as a symbol of a rich community, a group just playing guitar in front of their boarding house and just playing playstation as a symbol of the community of ordinary people.

Boarding house, through the boarding house boarding students have judged symbolically that the expensive boarding place is the place of the rich and vice versa.

University, choosing a college is not always based on the meaning of the college for prospective students, but the meaning of cost or money contained in the college becomes the main factor against the choices to be taken and all the actions that need to be done.

Hangout, the theory of symbolic interactionism also explains this that there is a process of interpretation as do this boarding students to something that is a hangout which then they give meaning to become a symbol of the social status of student boarding house.

Vehicle, in the environtment of boarding student is already inherent that boarding students who own a car like that is a student who is rich when compared to other boarding students who walk and 
despite having only motor vehicles battered and so forth. Means in these conditions boarding students have gone through the process of giving meaning to seuatu in social interaction. So that emerging rich and poor students are only based on the vehicles they have.

Food, for boarding students is a symbol of money because through the prices attached to the food directly also provides flexibility or restrictions on boarding students to buy the food. (i). Crisis Month, term of this crisis month has already had the same meaning among college students and used as a symbol of money is running out or their money is up.

According to Blumer the term symbolic interactionism refers to the peculiar nature of human interaction. The peculiarity is that humans translate and define each other's actions. The intermediate interpretation process between stimulus and response occupies a key position in the Symbolic Interactionist Theory. Thus, this social symbol of money is the result of the students' interpretation of the money to generate symbols in their social interaction process.

\section{The Symbolic Meaning of Money Among Boarding Students}

There is money there is friend, in this finding the position of money is so central in social interaction that more specifically determines the quantity and quality of social interaction among student boarding itself. There is no problem that money can not solve, so universally the money can be a way out of various problems.

Money is an instrument; a) Money is an instrument of entry into the community, through the money of board students having their own symbols of a particular community based on an assessment of their inter-values on which activities or communities they can access and which they can not access. b). Money is an instrument for enjoying entertainment, through the money of board students having their own symbols of a particular community based on an assessment of their intervalues on which activities or communities they can access and which they can not access. c). Money is an instrument of mobility, with having money will be easier to improve social status because it will be easier to finance every need in the process of achievement.

Money is a god, it can also be explained by the theory of symbolic interactionism which for some people this money is understood as a god and with the ownership of money the people also act like a god who acts without restrictions.

Money is a goal, every person interpret the purpose of his actions is related to the money factor. For example, college students who go to college to get a decent job with the size of the amount of salary that will be obtained from the job. Continuing education to a college like this is no longer to seek knowledge, or indeed it can still be obtained, but the orientation is no longer it, but it is a tool to earn a large salary by finding a job using a diploma as a condition of getting the job.

Money is life. In general, boarding students interpret money as a requirement of life, when not having money then it will create a feeling of boredom, feeling frustrated because not many things can be done including not being able to meet daily needs and campus activities let alone to enjoy entertainment.

Zelizer has given us an alternative approach to money that is the approach of social meaning of money. With this approach, therefore, he sees that money is neutral neither culturally nor socially anonymous. It is possible that "corrupt" values and social relations mutually transform money by investing it in social meanings and patterns. People strive, with various attempts to link money to specific times, places and social relationships (Damsar, 2006: 27-29).

Veblen has a lot of rhetorical treasures about money, but he writes about money not as a symbol of modern community life, but rather as a joy and show-off way as we find in the lives of primitive and medieval peoples (when money plays only a small part in social life). Simmel and Burke both stressed that money should be analyzed as a mode of communication, because the first thing that 
pokes our attention about money is that it has to be changed (transformed) into something else so that money can get its social meaning.

Based on some theories and expert opinion can be seen that money is not only as physical objects or medium of exchange in society, especially student boarding house. Moreover, money must also be seen in terms of meaning by the community itself because it affects the various aspects of the individual as well as the system as a whole.

\section{The Social Impact of Money Among Boarding Students}

The positive impact of money, are: (a) Easy to do mobility, meaning of the opportunity to continue college to college as one of the opportunities to achieve success and realize all the things that aspired; (b) Able to meet the needs of life, that all the needs have been attached to the price by humans, and to meet these needs then humans must be able to meet the price.

While the negative impact of money are: (a) Fake friends, friends for boarding students are also based on certain meanings and purposes that are not always purely because of the human nature of being friends, among them being friends of interest, and a certain purpose, and they will no longer want to be friends if the reason is no longer channeled or fulfilled; (b) Causingdebt,indebtedness has been attached as a symbol in the process of social interaction of boarding students. This in practice will determine the actions taken by the boarding students based on that symbol; (c) Conflict, conflict is the impact of various processes in social interaction, relating to money that has been embodied into the act of debt, sharing food and so forth, in this case any action of conflict is the meaning of something that has been attached to the meaning by boarding students.

\section{The Management Strategy Of Money of Boarding Students}

The management strategy of money of boarding students, are: (a) Saving it in ATM (Automatic Teller Machine), boarding students use ATM as much as possible in order to save money more safely, or as a means to be more efficient; (b) Avoiding spending on less important items, cost savings students' behavior, not wasteful, means boarding students really reflect that meaning in their actions to the money in the process of social interaction; (c) Deposite to the owner of boarding house, the act of entrusting money to the owner of boarding house is an action taken by boarding students because it is so difficult for them to manage their own finances. Thus it means to have taken action based on their meaning to the money; (d) Arranging the scheduled arrival of the money, this boarding student arranges the schedule of arrival of the shipment is adjusted to the extent to which he is able to manage its finances whether once a week, twice a month, once a month, or customized premises when their money runs out.

\section{Conclusions}

From the findings of this study researchers found nine social symbols of money among boarding students, are: lifestyle, clothing, community, boarding house, university, hangout, vehicle, food, and crisis month. From the findings of this research, researchers found six symbolic meanings of money, are: There is money there is friend, no problems that can not be solved by money, money is an instrument; (money is the instrument of entry into the community, money is the instrument to enjoy entertainment, and money is the instrument of mobility), money is god, money is the goal, money is "life".

The social impact of money among boarding students, are: a). From the findings of this study the researchers found two outlines of the positive impact of money among boarding students, are: easy to mobility and able to meet the needs of life. b). From the findings of this study, researchers found three outlines of the positive impact of money among boarding students, are: Fake friend, causing debt, and Conflict. 
In this study the researchers found four of other findings about the management strategy Of money of boarding students, are: saving it in ATM (automatic teller machine), avoid spending items that are less important, deposited to the owner of boarding house, and arrange the scheduling remittence.

\section{Acknowledgments}

In the implementation of research and preparation of this article, the authors get a lot of help and guidance from various parties. On this occasion the author would like to thank sincerely to: Mr. Erianjoni, M.Si. As Advisor I and Mrs. Fitri Eriyanti, M. Pd, P. hD As Advisor II, and Mr and Mrs Examiner: Prof. Dr. Azwar Ananda, MA, Dr. Fatmariza, M. Si, and Dr. Helmi Hasan, M Pd. Beloved parents who have supported in prayer, moral and material to the author, all lecturers in Padang State University Graduate Program who have trained and taught how to write, to all informants, and especially to all Graduate students colleagues of Padang State University, Studies Program of Social Sciences, who have given the time to provide guidance, advice and suggestions for the completion of this article.

\section{References}

Afrizal. (2008). Pengantar Metode Penelitian Kualitatif: Dari Pengertian Sampai Penulisan Laporan. Unand: Laboratorium Sosiologi FISIP Unand

Bungin, B. (2012). Metode Penelitian Kualitatif; Aktualisasi Metodologis Ke Arah Ragam Varian Kontemporer. Jakarta. Rajawali Pers

Damsar. (2006). Sosiologi Uang. Padang: Andalas University Press

Diana. (2011). Makna Sosial Uang Bagi Rumah Tangga Miskin, Studi Kasus: Rumah Tangga Miskin di Kelurahan Kuranji, Kecamatan Kuranji-Kota Padang. Tesis. Unand

Duncan. (1997). Sosiologi Uang. Yogyakarta: Pustaka Pelajar

Fitriawati. (2008). Makna Berbusana Muslim Bagi Mahasiswi FIP di Lingkungan Kampus UNP Padang. Tesis. UNP

Geertz, C. (1992). Tafsir Kebudayaan. Yogyakarta. Kanisius

Jauhari, H. (2010). Panduan Penulisan Skripsi dan Aplikasi. Bandung: Pustaka Setia

Johnson, D. (1994). Teori Sosiologi Klasik dan Modern Jilid1. Jakarta: Gramedia Pustaka Utama: Diterjemahkan Dari Sosiological Theory: Classical Founders And Contemporary Perspectives Oleh Robert M.Z Lawang

Kinloch, G. (2005). Perkembangan dan Paradigma Utama Teori Sosiologi. Bandung: CV Pustaka Setia

Kriyantono, R. (2007). Teknik Praktis Riset Komunikasi. Jakarta: Kencan

Littlejohn, S. (2009) . Teori Komunikasi Theories of Human Communication edisi 9. Jakarta. Salemba Humanika.

Mantra, I. (2000). Demografi Umum. Yogyakarta: Pustaka Pelajar

Moleong, L. (2000). Metode Penelitian Kualitatif. Bandung: Remaja Rosdakarya

Milles, M.B. and Huberman, M.A. (1984). Qualitative Data Analysis. London: Sage Publication

Pelly dan Menanti. (1994). Teori-Teori Sosial Budaya. Jakarta: Dirjen Pendidikan Tinggi Departemen Pendidikan dan Kebudayaan

Poloma, Margaret M. 1994. Sosiologi Kontemporer. Jakarta: PT. Raja Grafindo Persada

Ritzer, G. Sosiologi Ilmu Pengetahuan Berparadigma Ganda. Jakarta: PT Raja Grafindo Persada: Diterjemahkan Dari A. Multiple Paradigm Science

Rianto, S. (2009). Studi Tentang Makna Telepon Genggam di Kalangan Mahasiswa STKIP PGRI Sumatera Barat. Tesis. UNP

Smelser. (1987). Sosiologi Ekonomi. Bahana Aksa

Soekanto, S. Sosiologi Suatu Pengantar. Jakarta: Rajawali Pers 
Spradley. J. (1997). Metode Etnografi. Terjemahan Oleh Mizbah Zulfa Elizabeth. Yogyakarta: PT. Tiara Wacana

Suranto. (2010). Komunikasi Sosial Budaya. Yogyakarta: Graha Ilmu

Sutrisno dan Putranto. (2005). Teori-Teori Kebudayaan. Yogyakarta. Kanisius

Suyanto, B. Sosiologi Ekonomi: Kapitalisme dan Konsumsi di Era Masyarakat Post-Modernisasi. Jakarta: PT Kharisma Putra Utama

Wati. (2014). Pemaknaan Uang Pinjaman (Studi Fenomenologis tentang Makna Uang Pinjaman bagi Debitur BPR Delta Malang di Kelurahan Sisir Kota Batu. Jurnal. Universitas Brawijaya 